\title{
„Při takovém pohledu člověk téměř zapomene na tichou vlast." Slovinští spisovatelé - pražští studenti a doktorandi
}

\author{
Tone Smolej (Lublaň)
}

\begin{abstract}
Abstrakt
Na sklonku 19. století se na Univerzitu Karlovu v Praze prïhlásilo několik slovinských studentů, a to zejména díky významu profesora T. G. Masaryka. První doktorské disertační práce předložené slovinskými kandidáty patřily společenským vědám, napr. disertační práce věnovaná slovinskému školskému systému v reformačním období vznikla v roce 1910, pod vedením filozofa Františka Drtiny ji připravil publicista Ivan Lah. Volba tématu byla částečně ovlivněna Masarykovým pozitivním pohledem na husitství. Na počátku 20. století byli slovinští studenti druhou největši etnickou komunitou na pražské Právnické fakultě, kterou převyšovali pouze domácí Češi. K význačným právníkům se zařazují dále Anton Leskovec a Anton Novačan (ten získal doktorát v roce 1915). Slovinci pokračovali ve studiu až do dvacátých let v Praze, zejména jako studenti jejich krajana Matiji Murka. Pod Murkovým vedením Ferdo Kozak, další významný autor, vytvořil svou disertační práci lllyrismus a Slovinci (llirizem in Slovenci) v roce 1922.
\end{abstract}

\section{Klíčová slova}

slovinští spisovatelé; Karlova univerzita

\section{Abstract \\ „With Such a View, One Almost Forgets the Silent Homeland. "Slovene Writers - Students and Doctoral Students in Prague}

The close of the 19th century saw the enrolment of several Slovene students at the Charles-Ferdinand University in Prague, mostly owing to the fame of Professor Tomáš Masaryk. The earliest doctoral dissertations submitted by Slovene candidates belonged to social Sciences, but a dissertation on the Slovene school system during the Reformation was produced in 1910, prepared by Ivan Lah, a budding man of letters, and supervised by František Drtina. The choice of the theme was partly influenced by Masaryk's positive views of Hussitism. In early 20th century, Slovene students were the second largest ethnic community at the Prague Faculty of Law, outnumbered only by the Czech. Two outstanding lawyer-writers were Anton Leskovec and Anton Novačan (the latter obtained his $\mathrm{PhD}$ in 1915). Slovenes continued to study in Prague well into the 1920s, particularly as students of their fellow countryman Matija Murko. It was under Murko's supervision that Ferdo Kozak, another eminent author, produced his dissertation on Illyrism and Slovenes (llirizem in Slovenci) in 1922.

\section{Key words}

Slovene writers; Charles University in Prague

Článek vznikl v rámci projektu Historie doktorských dizertací slovinských kandidátů v rakousko-uherské monarchii (1872-1918), který financuje ARRS. Autor děkuje za pomoc dr. Andreji Šurlovi, bývalému lektorovi slovinštiny na Univerzitě Karlově. Název je převzat z novely Od srdce (Iz srca) Antona Leskovce. 
Roku 1882 byla v rámci Karlo-Ferdinandovy univerzity v Praze založena kromě německé i univerzita s českým vyučovacím jazykem. Franc Miklošič sice dříve v Panské sněmovně zapochyboval o tom, zda se Čechům podaří vychovat dostatek kvalifikovaných univerzitních učitelů, ale poté hlasoval pro takové rozdělení, jaké si Češi přáli, totiž na základě institucionální kontinuity, a nikoli ve formě zcela nové české univerzity, což obhajovali Němci. ${ }^{1}$ Starší profesoři se museli rozhodnout, kde budou nadále vyučovat, rozděleny musely být i společné prostory. V akademickém roce 1882/83 se bylo možné zapsat pouze na právnickou a filozofickou fakultu, kde začal přednášet Tomáš Masaryk, který se předtím habilitoval na vídeňské univerzitě. $\mathrm{V}$ devadesátých letech 19. století bylo na české univerzitě zapsáno již více studentů než na německé ${ }^{2}$ a ke konci století začali přicházet i Slovinci. Leckterý slovinský student se na českou univerzitu vydal kvůli proslulosti prof. Masaryka. Jedním z prvních byl Ivan Žmavc (1871-1956), který se po studiu ve Štýrském Hradci zapsal na českou filozofickou fakultu, kde navštěvoval Masarykovy přednášky z filozofie, a poté roku 1898 promoval na německé univerzitě s prací o svobodné vưli u Tomáše Akvinského. Žmavc, pozdějšś knihovník Klementina, byl spoluzakladatelem Masarykovy akademie práce. ${ }^{3}$ Poněkud odlišná byla cesta Dragotina Lončara (1876-1954), který se u Jaroslava Golla zapsal na antické a středověké dějiny a u Josefa Pekaře na dějiny novodobé. U Lubora Niederleho studoval archeologii a slovanské starožitnosti, u Jana Palackého národopis, horopis a vodopis. Po absolvovaných rigorózních zkouškách z geografie a filozofie Lončar roku 1902 promoval s prací O hustotě obyvatelstva a jeho sídel v Kranjsku, která se stala první obhájenou dizertací slovinského kandidáta na české univerzitě. Tak jako další zástupci jeho generace i Lončar navštěvoval Masarykovy přednášky z filozofie a sociologie, a již roku 1900 měl v Lublani přednášku s názvem Naše filozofično stališ̌̌e nasproti liberalismu, klerikalismu in socialni demokraciji (Náš filozofický postoj vůč liberalismu, klerikalismu a sociálni demokracii), která se teoreticky opírá o Masarykovu filozofii. Přednáška byla společně s dalšími referáty vydána v brožuře Kaj hočemo. Poslanica slovenski mladini (Co chceme. Poselstui slovinské mládeži), júž chtěli slovinští realisté Masarykovu myšlenku prosadit i na domácí půdě. ${ }^{4}$

Pavle Pestotnik (1879-1955), autor druhého doktorátu, se pro studium v Praze rozhodl, protože chtěl poznat českou sokolskou organizaci. Před studiem znal češtinu jen z Vymazalovy gramatiky. Stejně jako Lončar studoval i Pestotnik u Golla starší, u Pekaře novodobé dějiny a Václav Novotný mu přednášel Husité, táboři, bratři. Masaryka, u kterého navštěvoval sociologii, filozofii náboženství a historii malého národa, popsal později následovně: „Byl ostrým, věcným kritikem, nejen katolicismu jako všeho špatného a nezdravého, což později organizovaná katolická církev přimichala $k$ pưvodnímu čistému pojetí víry. Známa je jeho veřejná debata v Kolíně, kam Masaryk pozval k diskuzi o církevních a náboženských pro-

1 LUKAN, Walter: Franc Miklošič kot politik v gosposki zbornici. In: Miklošičev zbornik. Obdobja 13. Lublaň: SAZU, Filozofska fakulteta, 1992, s. 587.

2 HAVRÁNEK, Jan: Budováni čské univerzity a jeji působeni jako centra české vzdélanosti (1882-1918). In: Dějiny univerzity Karlovy III (1802-1918). Praha: Karolinum, 1997, s. 186.

3 GANTAR GODINA, Irena: T. G. Masaryk in masarykovstvo pri Slovencih. Lublaň: Slovenska matica, 1987, s. 134.

4 Tamtéž, s. 38. 
blémech vysoké církevni kruhy. Jeho výzva je známa: neničit víru, ale požadovat očištěni toho, co $k$ čisté Kristově nauce přidala náboženská spekulace učených teologů na církevních kongresech ve středověku a později. "5

Pestotnik cvičil u českého Sokola, a dokonce se zúčastnil sokolského sletu ve Lvově, který byl zahájen slavnostní mší. Zatímco polští sokolové během velebení klečeli, český náčelník vydal následující rozkaz: „Husưv národ stoji v pozoru!““. Roku 1906 složil Pestotnik rigorózní zkoušku z obecné a rakouské historie a u Masaryka filozofickou rigorózní zkoušku, promoval s prací Počátky národně politického života u Slovinců, později se stal profesorem, stařešinou slovinského Sokola a ministrem první slovinské vlády.

Jak můžeme usuzovat z pramenů, byli první slovinští doktorandi spíše humanitně orientováni a současně se pokoušeli myšlenky českého realismu (respektive masarykovství) a sokolství prosadit ve Slovinsku. Na podzim roku 1903 se na českou univerzitu zapsal první spisovatel - Ivan Lah -, který o dvě desetiletí později popsal své pocity takto: „Když jsem r. 1903 přišel na pražskou univerzitu, vedlo se mi jako leckterému mladému člověku, který v poměrech nového života hledá sebe sama. Univerzita byla rozmistěna po rüzných starých budovách Karolina a Klementina - filozofické přednášky probihaly ve velkém tzv. Lázeňském sále a na Malé Straně. To vše mělo negativni vliv na začátečnika, který se ve velkém městě sotva vyznal. Často se stalo, že jsem posluchárnu našel, když už přednáška skončila. Kromě toho mě zajimala knihkupectví a antikvariáty se svými výlohami a častokrát jsem si za pár šestáků koupil knihu, která mě zaujala, a odešel do parku, kde se tímto způsobem studovalo př́jemněji než na přednáškách, zejména proto, že jsem ještě dobře neovládal jazyk. Tak se mưže studium stát nebezpečným pro toho, kdo chce univerzitu absolvovat. Ačkoli jsme měli v klasické fllologii odborniky, kteři byli vynikajicí prednášejici, jako Novák, Král, Vysoký, Groh a další, nemohl jsem $v$ této vědě najit skutečný smysl. "7

Josef Král, který Lahovi přednášel řeckou metriku a gramatiku attického dialektu, se habilitoval ještě na nerozdělené univerzitě, a Robert Novák, který se roku 1882 stal vůbec prvním profesorem habilitovaným na české univerzitě, římskou rétoriku, tragédii a lyriku. U Hynka Vysokého poslouchal Lah řeckou mytologii a u Františka Groha Platona, Homéra a řeckou tragédii. Kromě klasické filologie si Lah zapisoval také slavistické předměty, František Pastrnek, Miklošičův žák, tehdy přednášel staroslověnštinu i českou, moravskou a slovenskou dialektologii. Lah později napsal, že ho slavistika zajímala více po literární než po jazykové stránce, měsíce mu tak ubíhaly v nerozhodném přemýšlení, ale brzy našel pravého učitele: „Jednou mě cesta přivedla na přednášku z historie pedagogiky. Přednášel prof. Drtina. Velký sál byl zcela zaplněný, asi 200 lidí poslouchalo s jakousi posvátnou horlivosti přednášejicího. Hovořil o Rousseauovi. Jeho projev byl výrazný a jasný, přednáška precizni a zajímavá. Přede mnou se rodila podoba velkého cestovatele, neklidného ducha, který opustil své rodné město Ženevu a vydal se do světa, aby se stal hlasatelem velkých nových myšlenek. Od té chvile jsem byl věrným posluchačem suého profesora, a když jsem se s ním při jedné

5 PESTOTNIK, Pavel: Moja življenjska slika. San Ramon: Vlado Bevc, 1995, s. 33.

6 Tamtéž, s. 9.

7 LAH, Ivan: Prof. dr. Drtina (1861-1925). Popotnik 46, 1925, s. 38. 
př́ležitosti osobně seznámil, byl potěšen, že má mezi posluchači i Slovince, a prosil mě o nějaké informace o našem školství, jelikož neměl přesné údaje."

Po roce 1904/1905 Lah u tohoto profesora navštěvoval historii pedagogiky, reformní směry ve středoškolské didaktice a historii novodobé filozofie v období renesance a reformace. Drtina platil za stoupence profesora Masaryka. Přestože Lah si u něj v době studia zapsal pouze filozofický seminář a přednášku o Dostojevském, z Knihy vzpominek (Knjiga spominov) vyplývá, jak hluboce ho Masaryk ovlivnil: „[Masarykovy] přednášky byly zcela naplněny; všichni poslouchali s jakousi svatou pobožností. Přestože jsem ještě zcela neovládal jazyk, cítil jsem vliv jeho osobnosti: jeho krátké úsečné věty vyslovované z hlubokého vnitřního přesvědčení, s vážným slovem a charakteristickými gesty jeho pravé ruky, jeho pohled a celý fenomén, vše v sobě mělo cosi lákavého, přitažlivého a mnohé jeho věty doznívaly $v$ duši ještě dlouho poté, kdy už jsme odcházeli na procházku do zahrady Kinských. Zde se vysvětlovalo evangelium života, evangelium národností, evangelium nového slovanstvi." 9

Masaryk chtěl mládež, která k němu přilnula, ochránit před bezvěrectvím a náboženskou indiferentností, jelikož pouze na základě víry je možné vychovávat lepšího a štastnějšího člověka. Mladé upozorňoval na Jana Husa a další české reformátory, kteří chtěli národům vrátit čistou Kristovu církev, kde se modlí k Bohu v duchu a pravdě. ${ }^{10}$ Jakmile jeho boj o zbožnost u české mládeže vyvolal vzpomínky na husitskou tradici, začali se i slovinští masarykovci zajímat o naši reformaci. Masarykovy podněty a Drtinovy přednášky o renesanci a reformaci ovlivnily výběr tématu doktorátu, který začal Lah psát začátkem roku 1908: „Musím prostudovat celou renesanci a celou reformaci, protože škola je vždy ozvěnou doby. Musím ř́ct, že toto obdobi je velmi zajimavé, a jsem vskutku spokojený, že jsem si ho zvolil. Myslím, že i moje práce Naše školstui v době reformace bude velice dobrá. Prof. Drtina byl opravdu spokojený, když jsem mu to sdèlil, nicméně mě trochu udivilo, když mi řekl, že prvni rigorózní zkouška bude z celé filozofie a z celé pedagogiky a druhá z klasické filozofie. Je to obsáhlá záležitost, no, ale slíbil mi pomoc. Plán je nyní pevný a pracovník pilný a zdravý." 11

Když psal tyto řádky, připravoval Lah kulturně-historickou studii Primož Trubar a naše reformace (Primož Trubar in naša reformacija), v níž také cituje Masarykovu řečnickou otázku, zda jsou Češi skutečně národem Husovým. Protože slovinský národ je klerikální, zotročený a servilní, své reformátory nezná nebo se za ně stydí. ${ }^{12}$ Již dř́ive zveřejnil novelu Predikant, o duchovním, který chce učit lásku a kázat lidem čistou pravdu, ale při pronásledování ho zabijí jako bezvěrce. O dva roky později absolvoval Lah nejprve rigorózní zkoušku z filozofie u Drtiny a Masaryka s výborným hodnocením. Druhá rigorózní zkouška byla nakonec ze slovanské, nikoli z klasické filologie. U Pastrnka dostal „výborně“ a u Polívky „dostatečně“.

Originál doktorské dizertace dnes již není v evidenci, ale Lah práci zveřejnil ve slovinštině v časopise Popotnik. Středověk popisuje pomocí citátů z Prešernova Křtu na Savici

8 Tamtéž.

9 LAH, Ivan: Knjiga spominov. Ječe. Moja pot. Dan 1914. Lublaň: Tiskovna zadruga, 1925, s. 26.

10 Tamtéž, s. 36-37.

11 Ivan Lah, dopis Juli Vouk. Vinohrady, 19. 1. 1908. NUK Rz Ms 1633.

12 LAH, Ivan: Primož Trubar in naša reformacija. Kulturno-historična študija. Lublaň: Blaznik, 1908, s. 7. 
(Krst pri Savici). Obětování Bogomily vysvětluje ve světle tehdejšího supranaturalismu a supraracionalismu. Také Črtomir je pro něj středověkým člověkem, protože se ze svých hříchů kaje a slouží církvi. Středověk je pro Laha ${ }^{13}$ obdobím, kdy neexistují důkazy o slovinském kulturním životě: „Slovinský otčenáš, apoštolské vyznání víry a přísaha, to je vše, co kulturního tehdejší slovinský národ potřeboval.“ S větším nadšením promluvil Lah o hnutích, jež přicházela ze severu a jihu, o italské renesanci a německé reformaci, které vysvětluje i pomocí monografie Františka Drtiny Myšlenkový vývoj evropského lidstva a dalších jeho prací. V Itálii byla půda pro renesanci příznivější než pro reformaci, zatímco v Německu tomu bylo právě naopak. Lah se dále zabývá Trubarovými pohledy na školství, které vyjádřil v díle Cerkvena ordnunga, že žádná země, ani město, ani obec nemohou být bez škol, žáků a učených lidí. Lah polemizuje s Ilešičovými ${ }^{14}$ tezemi, že je nutné opatrně přijímat tvrzení o národním charakteru protestantského školství, nebot zdůrazňuje, že nižší školství bylo rozhodně slovinské. Drtinova teze, že po Melanchthonově smrti nebyla ani jedna univerzita a ani jedna škola, kde by nebyli jeho žáci, u nás platí pro školu v Kršku a později v Lublani, protože je vedl magistr Adam Bohorič. Konec reformace a školství roku 1598 považuje $\mathrm{Lah}^{15}$ za „konec našeho proního kulturního života“. Odmítá názory některých historiků, že reformace byla pouze kopií německého luteránství, a svoji práci uzavírá Drtinovou myšlenkou, že školství každého období odpovídá jeho kulturnímu charakteru, a také zdůrazňuje, že reformace v lásce ke knize a výchově zanechala dědictví, které „nám musi být svaté jako trvalý základ naši národni kultury“. ${ }^{16}$

Oproti Filozofické fakultě v Praze, kde bylo na začátku století zapsáno pouze devět slovinských studentů, jich bylo na Právnické fakultě hned 31. Slovinští studenti představovali jeden a půl procenta všech, což znamená, že byli za Čechy $(97,6 \%)$ druhou největší národní komunitou. ${ }^{17}$ Jedním z nich byl také Josip Murn, který navštěvoval přednášky z německého, římského a autorského práva. V akademickém roce 1908/09 akademický senát navrhl, aby byly na české univerzitě určité přednášky až do založení slovinské univerzity vedeny ve slovinštině, což však ministerstvo zamítlo. ${ }^{18} \mathrm{~V}$ akademickém roce 1913/14 se počet studentů zdvojnásobil a představoval už tři procenta. ${ }^{19}$

I přes propagandu proti pražské univerzitě, která Masaryka a Drtinu prohlašovala za neznabohy, ${ }^{20}$ se do české metropole začali vydávat výrazně nábožensky orientovaní studenti, kteří roku 1910 založili slovinský katolický akademický spolek Dan (Den). Jedním z jeho členů byl spisovatel Anton Leskovec, který v dosud neznámém dopise rodině sděloval, jak všichni členové spolku po několikadenních duchovních cvičeních u jezuitů

13 LAH, Ivan: Šolstvo za časa reformacije na Slovenskem. Popotnik 31, 1910, s. 177.

14 ILEŠIČ, Fran: Trubar in njegova doba. In: Trubarjev zbornik. Lublaň: Slovenska matica, 1908.

15 LAH, Ivan: Šolstvo za časa reformacije na Slovenskem. Op. cit., s. 311.

16 Tamtéž, s. 345.

17 HAVRÁNEK, Jan: Počty a pưvod posluchačủ pražských univerzit v letech 1802-1918. In: Dějiny univerzity Karlovy III (1802-1918). Praha: Karolinum, 1997, s. 364.

18 HAVRÁNEK, Jan: Budováni české univerzity a jeji pưsobeni jako centra české vzdělanosti (1882-1918). In: Dějiny univerzity Karlovy III (1802-1918). Praha: Karolinum, 1997, s. 193.

19 HAVRÁNEK, Jan: Počty a pưvod posluchačů pražských univerzit v letech 1802-1918. Op. cit., s. 367.

20 BENEDETIČ, Ana: Poti do univerze. Lublaň: Studia Humanitatis, 1999, s. 225. 
vstoupili do Mariiny společnosti: „Přijimal nás sám jeho eminence kniže a arcibiskup Lev hrabě Skrbenský; sám nám připnul medaile. Rovněž obřad je jiný než v Kraňsku. Nejkrásnějši je př́isaha. Poklekne se, tři prsty se položi na evangelium, které drži kardinál, odřiká se př́saha, políbi se kardináliov prsten a evangelium. Bylo to vskutku krásné. " 21 Protože jmenování Skrbenského pražským arcibiskupem přijala veřejnost jako protičeský počin, ${ }^{22}$ je jasné, že se členové spolku Dan neidentifikovali s Masarykovými myšlenkami. Leskovec, který už jeden semestr studoval ve Vídni, navštěvoval u Leopolda Heyrovského, otce prvního českého nositele Nobelovy ceny, římské dědické právo a u Jaromíra Čelakovského, syna Prešernova kolegy, historii práva v českých zemích. V pozdějších semestrech poslouchal u Emanuela Tilsche rakouské státní právo, u Cyrila Horáčka finanční vědu a u Karla Hermanna Otavského obchodní právo. Břetislav Foustka mu přednášel moderní stát. V době studia Leskovec napsal i své první prozaické dílo, které je obohaceno pražskými impresemi: „Chodil jsem, jako každý den, po vltavských nábřežích. Sem a tam mě oko donutilo, abych se zastavil, opřel o železné zábradli a zahledèl se na tu nádheru, která je vlastni jen stále mladé a krásné zlaté Praze. Širokým korytem rozlévala temná hluboká Vltava své vody pomalu, avšak silně, v ni se zrcadlily krásné nové paláce, kterým západ slunce v posledních chvilkách zlatil okna. Dole pak králouské Hradčany s monumentálním su. Vítem, před tebou okouzlujicí Petřin se suými parky. Nalevo stráži hrdý Vyšehrad se svoji historii a napravo celá Praha se stovkami věži, jako mořský přistav. Kdo by ti měl za zlé, že při takovém pohledu člověk téměř zapomene na tichou vlast s jejimi zelenými údolími, rozkošnými jezery, zasněženými horami."23

O několik let později se do studentského spolku Adrija zapsal Anton Novačan, který však v Praze štastný nebyl: „Bojuji s celým světem. Z Adrije mě zitra večer nejspiš vyženou, protože kladu odpor a mám chyby. Ve spolku jsou totiž sami slavni Sokratové a Lykúrgové a všichni bez chyb. Řekl jsem, že neznám národ, ale pouze sebe a že s národem nechci nic mit, že ze sebe hodlám o to vice udělat - a jsou rozhořčeni. Nevís, drahý můj, jak jsou hloupi, pokrytečti a jezuitsky radikální."24

Novačan jinak na Právnické fakultě v prvních semestrech poslouchal historii římského, německého a českého práva i církevní právo, ve vyšších semestrech rakouské právo, ekonomii a statistiku. Zapsal se i na Drtinovy přednášky o filozofii a Chytilovy o Leonardu da Vincim. V jeho pozůstalosti se dochovalo několik osvědčení: kolokvia u Miloslava Stiebera (Německá právni historie), u Heyrovského (Historie a systém římského práva) a u Roberta Maršana (Vývoj ústavy rakouského cisařství, 1860-67) absolvoval velmi dobře, u Karla Kadlece (Rakouská státni historie) a Hobzy (Církevni právo) dokonce s výborným prospěchem. ${ }^{25}$ Po rigorózních zkouškách z historie práva, rakouského práva a státovědy, které skládal částečně v češtině a částečně v němčině, byl roku 1915 promován doktorem práv.

21 Anton Leskovec, dopis rodině. Praha, 9. 12.1910. A. Leskovec. Korespondence. Zgodovinski arhiv Škofja Loka. SI-ZAL-ŠKL/0066. Družina Kušar. T. e. 1. P. e. 15. KRONTHALER, M.: Skrbenský von Hříště, Leo. OBL 12, 2014, s. 334.

23 LESKOVEC, Anton: Iz srca. In: Zbrano delo 1. Lublaň: Državna založba Slovenije, 1991, s. 8.

24 Anton Novačan, dopis Antonu Debeljaku. Praha, 17. 6.1911. NUK Rz. Ms 1190.

25 Anton Novačan. Zapuščina. NUK Rz Ms 1645. 
Tehdy však již zư̌ila první světová válka. Kvůli mobilizaci Leskovec absolvoval pouze první, právně historickou rigorózní zkoušku, Pestotnik bojoval společně s Janem Masarykem a Lah prožil část války ve vězení.

Po vyhlášení Československa se stal Masaryk prezidentem republiky, na podzim roku 1918 se univerzita přejmenovala na Karlovu univerzitu, profesor Drtina se s ministrem školství podílel na př́ipravě školské reformy, mnoho dalších profesorů a docentů rovněž nastoupilo na nové funkce ve vládě a v parlamentu. ${ }^{26} \mathrm{~V}$ souladu s novým jugoslávským režimem zohledňovala univerzitní statistika nadále Srby, Chorvaty a Slovince společně, na začátku dvacátých let studovalo na Karlově univerzitě hned 759 státních př́islušníků Království a představovali přes osm procent všech studentů; Slováků, kteři již získali novou univerzitu v Bratislavě, bylo o polovinu méně. Po roce 1921 začal počet jižních Slovanů značně klesat a ve třicátých letech se zastavil pod půl procentem. ${ }^{27}$ Jedním z početných jugoslávských studentů byl Ferdo Kozak, který se po dvou semestrech ve Vídni a v Záhřebu v letním semestru 1919 zapsal na Karlovu univerzitu, kde u Maximiliána Křepinského studoval francouzskou historickou gramatiku, u Václava Tilleho historii francouzské literatury a literární komparatistiku. Měl rovněž několik hodin francouzského lektorátu, kde se zabýval francouzským realismem a moderní poezií. Na slavistice kromě Pastrnekových přednášek ze staroslověnštiny poslouchal Polívkovy přednášky o srbské a ruské literatuře. Zapsal si i Máchalovy přednášky o české literatuře a o historii slovanských literatur od osvícenství do realismu. U tohoto profesora měl budoucí dramatik také seminář z Čechovových dramat. Ve stejnou dobu v Praze studovali i France Mesesnel, který u Karla Chytila navštěvoval dějiny umění, a Josip Vidmar. Ten v Praze zamýšlel studovat cokoli nebo vlastně nic, protože se chtěl nejprve věnovat dramaturgii, ale nakonec si zapsal přednášky u Máchala, Pastrnka a rodáka Rostohara. Ve Tuárích (Obrazi) popisuje, jak trávili večery na Vinohradech ve slovinské hospodě Pipan, kde byli Kozak a Mesesnel spíš hladoví než sytí, jelikož každou ušetřenou korunu utratili za knihy. V blízkém Německu, které tehdy prožívalo svoji nejkatastrofálnější inflaci, je mohli kupovat neobyčejně levně a navštěvovali také koncerty české filharmonie. Společně diskutovali o Sovětském svazu, který tehdy vedl Lenin, o filozofii a samozřejmě o literatuře: „O literatuře si [Kozak] rád povídal, řekl bych impresionisticky. Analýzy a estetické úvahy rád nemèl, prestože, pokud vím, četl v té době proslulého českého kritika F. X. Šaldu. " ${ }^{28} \mathrm{Jinak}$ byl Kozak také předsedou jugoslávských studentů, poslanec Ivan Hribar mu zaopatřil pěkný byt a zval ho na řadu audiencí.

Roku 1920 přijal pozvání na Karlovu univerzitu téměř šedesátiletý prof. Matija Murko, jenž měl na konci ř́ijna již inaugurační přednášku o předchůdcích ilyrismu, ${ }^{29}$ a poté začal na nově založené katedře jihoslovanských jazyků a literatury s přednáškami o ilyrismu: „Zájem o jihoslovanské jazyky a literatury u Čech io nebyl nijak velký; stejně si stěžovali i ostatní

26 HAVRÁNEK, Jan: Univerzita Karlova, rozmach a perzekuce 1918-1945. In: Dějiny univerzity Karlovy IV (1918-1990). Praha: Karolinum, 1998, s. 20-22.

27 Tamtéž, s. 26.

28 VIDMAR, Josip: Obrazi. Lublaň: Državna založba Slovenije,1979, s. 305.

29 JENSTERLE-DOLEŽAL, Alenka: Arheologija konteksta. Murkovo nastopno predavanje na Karlovi univerzi v Pragi. In: Sto let slovenistiky na univerzitě Karlově v Praze. Praha: Filozofická fakulta, 2014, s. 56-67. 
profesoři slovanských literatur a jazyků. Hlavni důvod spočival v tom, že nebyla vyřrě́ena otázka výuky slovanských jazyků na střednich školách. Byl to circulus vitiosus, nedostávalo se kandidátů na slovanské jazyky na středních školách, a ti zase nechtěli studovat tyto jazyky, pokud neměli zajištènu budoucnost. Jádro posluchaču tvořili $i$ u mne Jugoslávci, zejména stipendisté vyššich ročniki̊, s nimiž bylo možno v seminárích pěkně pracovat. “30

Jedním z nich byl i Kozak, který si u Murka tehdy zapsal seminář a ke konci roku 1920 se s ním dohodl na tématu disertace, o čemž píše Ivanu Prijateljovi: „V proni části se zamýšlim dotknout charakteristiky romantického obdobi obecně, potom jeho vlivu na Slovany, vykreslit začátek ilyrismu, zejména kořeny, z nichž vyšel. Také bych rád zdưraznil jeho hodnoty $v$ uměleckém a politickém ohledu. V druhé části hodlám podat krátkou kulturné-politickou historii Slovinců v té době, do niž bych poté začlenil fenomén ilyrismu u nás (hlavni Ilyrové). A nakonec nástin následků ilyrismu u nás a u Chorvatů. [...] Rád bych totiž shrnul vše, co se odehrávalo $v$ rüzných slovinských centrech, v jeden celek, vypracoval timto zpưsobem obraz tehdejšich pomérů a tím nějak změřil, jak hluboce u nás ilyrismus vi̊bec rozvinul své kořeny a také, nakolik byl $v$ přirozeném národním vývoji jeho fenomén připravený a oprávněný."31

Na sklonku roku 1921 Kozak již informoval, že svoji disertaci »začal oblékat do definitivních šatů «, přestože mu jde psaní pomalu od ruky. Mnoho o ní debatoval i s prof. Murkem, který mu sdělil, že ho v Záhřebu požádali, aby napsal článek o nutnosti jednotného jugoslávského jazyka, ale odmítl. ${ }^{32}$ Po absolvované dvouhodinové rigorózní zkoušce ze slovanské filologie a historie moderních literatur, kterou u Murka a Tilleho složil na výbornou, a jednohodinové zkoušce z filozofie byl Kozak v létě roku 1922 promován doktorem filozofie.

V archivu Karlovy univerzity se dochovala Kozakova disertace s názvem Ilyrismus a Slovinci (Ilirizem in Slovenci), která má 157 stran. V úvodních kapitolách Kozak pojednával o Herderových vlivech na Jana Kollára, což bylo staré Murkovo téma. Dále vylíčil přijetí českého básníka v Chorvatsku, především ve světle ilyristických snah. Podrobně popsal slovinské kulturně-politické postavení na začátku 19. století i roztříštěnost slovinského organismu, nebot' v době obrození ještě neexistoval jednotný slovinský spisovný jazyk uznávaný vší inteligencí: „A současně paralelně s myšlením a cítěním národa většinu této inteligence nevázalo plné vědomí jednoty slovinského organismu. " ${ }^{33}$ Ústřední místo v disertaci má patriotická škola ve Štýrském Hradci, zejména Stanko Vraz. Kozak se zaměřil i na psychické důvody jeho přestoupení k ilyrismu a současně popsal reakce na něj, zvláště u Prešerna, který byl přesvědčen o nemožnosti realizace myšlenky slévání srbského a slovinského jazyka. V závěru vyjmenoval pozitivní hlediska ilyrismu i ve světle aktuálních jugoslávských politických událostí: „Vlastenectvi probuzené v ilyrské myšlence tato inteligence navlékla na osu společného cítění, aby si v proni radě uvědomili svoji národni př́slušnost a zároveň tímto krokem pristoupili $k$ problému potreby společného vyjadřováni - jednotného slovinského spisovného jazyka. Hledíce všichni jedním směrem, byli donuceni $k$ hledáni jednoho prostředku. Vliv

30 MURKO, Matija: Spomini. Lublaň: Slovenska matica, 1951, s. 177.

31 Ferdo Kozak, dopis Ivanu Prijateljovi. Praha, 19. 1. 1921. NUKRz Ms 895.

32 Ferdo Kozak, dopis Ivanu Prijateljovi. Praha. 5. 11. 1921. Tamtéž.

33 KOZAK, Ferdinand: Ilirizem in Slovenci. Archiv Univerzity Karlovy, 1922, s. 47. 
ilyrské myšlenky v jeji posledni fázi zasáhl právě toto jazykové hnuti a nepř́mo zpưsobil obrození slovinského spisovného jazyka. Tak myšlenka jazykového a literárního sjednoceni jižních Slovanů posílila a upevnila růst slovinského národa, hřejivá - ačkoli sama jako cíl mimo organické potřeby - vše v přirozenosti dané perspektivy vývoje. Myšlenka jugoslávské vzájemnosti klićila z generace na generaci, dokud v naši době politickým sjednocením Jugoslávců konečně nenašla svoji reálnou tvár. “34

Hrstka slovinských spisovatelů, která studovala na nejbližší rakouské univerzitě se slovanským vyučovacím jazykem, byla v Praze mile přijata. Charizmatičtí profesoři a novější metody jim umožnili doktorské disertace, které by ve Vídni nebo ve Štýrském Hradci nebyly realizovatelné.

Ze slovinštiny přeložil Petr Mainuš

\section{Literatura}

BENEDETIČ, Ana: Poti do univerze. Lublaň: Studia Humanitatis, 1999.

DRTINA, Fran: Miselni razvoj evropskega človeštva. Do slovinštiny přeložil J. A. Glonar. Lublaň: Omladina, 1908-1909.

GANTAR GODINA, Irena: T. G. Masaryk in masarykovstvo při Slovencih. Lublaň: Slovenska matica, 1987.

GANTAR GODINA, Irena: Slovenski doktorji v Pragi (1882-1916). Zgodovinski časopis 44, 1990, s. 451-455.

HAVRÁNEK, Jan: Budování české univerzity a její pưsobeni jako centra české vzdèlanosti (1882-1918). In: Dějiny univerzity Karlozy III (1802-1918). Praha: Karolinum, 1997, s. 183-206.

HAVRÁNEK, Jan: Počty a pi̛vod posluchaču pražských univerzit v letech 1802-1918. In: Dějiny univerzity Karlowy III (1802-1918). Praha: Karolinum, 1997, s. 354-367.

HAVRÁNEK, Jan: Univerzita Karlova, rozmach a perzekuce 1918-1945. In: Dějiny univerzity Karlovy IV (1918-1990). Praha: Karolinum, 1998, s. 19-60.

ILEŠIČ, Fran: Trubar in njegova doba. In: Trubarjev zbornik. Lublaň: Slovenska matica, 1908, s. V-XXXII.

JENSTERLE-DOLEŽAL, Alenka: Arheologija konteksta. Murkovo nastopno predavanje na Karlovi univerzi v Pragi. In: Sto let slovenistiky na univerzitě Karlověv Praze. Praha: Filozofická fakulta, 2014, s. 56-67.

KOZAK, Ferdinand: Ilirizem in Slovenci. Archiv Univerzity Karlovy, 1922.

KRONTHALER, M.: Skrbenský von Hřiště, Leo. OBL 12, 2014, s. 334.

LAH, Ivan: Predikant. In: Vaška kronika. Lublaň: Narodna Založba, 1907, s. 138-169.

LAH, Ivan: Primož Trubar in naša reformacija. Kulturno-historična študija. Lublaň: Blaznik, 1908.

LAH, Ivan: Šolstvo za časa reformacije na Slovenskem. Popotnik 31, 1910, s. 173-180, 204-211, 241245, 269-277, 302-312, 342-345.

LAH, Ivan: Profesor Fran Drtina. Popotnik 32, 1911, s. 321-322.

34 Tamtéž, s. 156-157. 
LAH, Ivan: Prof. dr. Drtina (1861-1925). Popotnik 46, 1925, s. 37-40.

LAH, Ivan: Knjiga spominov. Ječe. Moja pot. Dan 1914. Lublaň: Tiskovna zadruga, 1925.

LESKOVEC, Anton: Iz srca. In: Zbrano delo 1. Lublaň: Državna založba Slovenije, 1991, s. 7-14.

LUKAN, Walter: Franc Miklošič kot politik v gosposki zbornici. In: Miklošičev zbornik. Obdobja 13.

Lublaň: SAZU, Filozofska fakulteta, 1992, s. 577-590.

MURKO, Matija: Spomini. Lublaň: Slovenska matica, 1951.

PESTOTNIK, Pavel: Moja življenjska slika. San Ramon: Vlado Bevc, 1995.

VIDMAR, Josip: Obrazi. Lublaň: Državna založba Slovenije, 1979.

VITOROVIČ, Nenad: Protestantizem v polemikah ob štiristoletnici Trubarjevega rojstva. Ljubljana: Filozofska fakulteta, 2006.

red. prof. dr. Tone Smolej

Oddelek za primerjalno književnost in literarno teorijo

Filozofska fakulteta, Univerza v Ljubljani

Aškerčeva cesta 2, SI-1000 Ljubljana, Slovinsko

tone.smolej@ff.uni-lj.si 